\title{
THE CONTRIBUTION OF AL-SYA'RAWI TO THE DEVELOPMENT OF TAFSIR: STUDY ON THE BOOK OF TAFSIR AL-SYA'RAWI
}

\author{
Mhd. Idris \\ Universitas Islam Negeri (UIN) Imam Bonjol Padang, mbdidris@uinib.ac.id \\ (c) (7) (2) \\ (C)2020 by the authors. Submitted for possible open access publication under the terms and conditions \\ of the Creative Commons Attribution-ShareAlike 4.0 International License (CC-BY-SA) \\ license (https://creativecommons.org/licenses/by-sa/4.0/ \\ doi DOI: http://dx.doi.org/10.30983/fuaduna.v4i2.3599 \\ Diterima: 12 Oktober $2020 \quad$ Direvisi: 14 Desember 2020 \\ Diterbitkan: 31 Desember 2020
}

\begin{abstract}
This research discusses the contribution of Imam al-Sya'rawi in the field of interpretation with his phenomenal work Tafsir al-Sya'rawi. This article aims to find out about the general profile of the author of the Tafsir al-Sya'rawi, the background of the tafsir, the method, and style of interpretation as well as the strengths and weaknesses of this Sya'rawi's interpretation. This research is library research that is descriptive-analytical. The primary source used is the book of Tafsir al-Sya'rawi and literature related to this discussion as secondary sources. The results showed that the book of Tafsir al-Sya'rawi was the work of a prominent scholar from Egypt named Sheikh Muhammad Mutawally al-Sya 'râwi, born in 1911 in Egypt. The name of Tafsir al-Sya'rawi is taken from the original name of the writer. This interpretation uses the tablili method and is characterized by al-adab al-ijtima'i. This interpretation is presented with nuances that are in direct contact with social themes, through a fairly simple language technique. But the drawback is that there is no reference source when quoting the opinions of other scholars and there is no assessment of the quality of the hadiths quoted.
\end{abstract}

Keywords: Tafsir al-Sya'rawi; Tablili Method; Style of Interpretation.

\begin{abstract}
Abstrak
Penelitian ini membahas tentang kontribusi Imam Sya'rawi di bidang tafsir dengan karya fenomenalnya Tafsir al-Sya rawi. Tulisan ini bertujuan untuk mengetabui tentang profil umum penulis Tafsir Sya'rawi, latar belakang tafsir, cara dan gaya tafsir, serta kekuatan dan kelemahan Tafsir al-Sya'rawi ini. Penelitian ini merupakan penelitian pustaka yang bersifat deskriptif-analitik. Sumber primer yang digunakan adalah kitab Tafsir al-Sya'rawi dan literatur terkait pembahasan ini sebagai sumber sekunder. Hasil penelitian menunjukkan babwa kitab Tafsir al-Sya'rawi merupakan karya seorang ulama terkemuka dari Mesir bernama Syekh Mubammad Mutawally al-Sya râwi, labir pada tabun 1911 di Mesir. Nama Tafsir al-Sya'rawi diambil dari nama asli penulisnya. Tafsir ini menggunakan metode tahlili dan bercirikan al-adab al-ijtima'i. Interpretasi ini dihadirkan dengan nuansa yang bersentuban langsung dengan tema sosial, melalui teknik bahasa yang cukup sederhana. Tetapi kekurangannya adalah tidak ada sumber referensi ketika mengutip pendapat ulama lain dan tidak ada penilaian kualitas badits yang dikutip.
\end{abstract}

Kata Kunci: Tafsir al-Sya'rawi; Metode Tahlili, Gaya Penafsiran. 


\section{INTRODUCTION}

The study of al-Qur'an has always experienced developments from period to period, from the period of the Prophet Muhammad SAW or the period of the revelation of the al-Qur'an itself to the present. This is proof that the Qur'an is relevant and applicable in all times and places. ${ }^{1}$ One of the studies on the Qur'an is in the form of interpretation. Because today it is not possible to understand the Qur'an from the current Mushafs that we have and their interpretations as easily as it was in the early periods. The reason for this that the Quran was not arranged properly and chronologically; divisions, paragraphs, chapters were disorganized; some errors were made when copying; there have been degenerations in the Arabic Language while there were also developments and in addition to that, many religious books were written in the name of the religion so that boundaries have been put between the Qur'an and the people. ${ }^{2}$ However, along with the times, it requires many mufassirin (interpretation experts) apply many methods to interpret the verses in the Qur'an ${ }^{3}$ with the aim of answering problems that occur among Muslims. Thus, Muslims can easily get instructions from the Qur'an through the thoughts of the mufassir.

In this contemporary period, many books have also appeared, one of which is the book of Tafsir al-Sya rawi by a prominent egyptian scholar named Sheikh Muhammad Mutawally al-Sya râwi, who was born in 1911 in Daqadus, Daqhilia province, Egypt. ${ }^{4}$ This interpretation is one of several Tafsirs that were born in this modern era

1Ziauddin Sardar, Reading The Qur'an: The Contemporary Relevance Of The Sacred Text Of Islam (Oxford University Press, 2011).

${ }^{2}$ Hakk1 Y1lmaz, The Division By Division English Interpretation Of The Qur'an In The Order Of Revelation (Hakk1 Y1lmaz, 2020), 11.

${ }^{3}$ Lukmanul Hakim Et Al., "Qur'anic Interpretation Method And Its Impact On Contemporary Interpretation," Jurnal Ushuluddin 26, No. 2 (December 13, 2018): 143, Https://Doi.Org/10.24014/Jush.V26i2.4577.

${ }^{4}$ Muhammad Rizqi, "Tafsir Ilmi Dalam Kitab Tafsîr Al-Syarâwi," Al-Furqan 3, No. 2 (2016): 71. which contains explanations and contents of the verses of the Qur'an.

This research is library research which is descriptive-analytical. The primary source used is the book of Tafsir al-Sya'rawi and literature related to this discussion as secondary sources. This study aims to introduce readers to the sociohistorical setting of the author of this tafsir, the general profile of the tafsir and how the method and style of interpretation in this book

\section{BIOGRAPHY OF AL-SYA'RAWI}

\section{The Name and Lineage of al-Sya'rawi}

The full name of al-Sya rawi is Muhammad Mutawalli al-Sya rawi. He is a wellknown figure who was born in the land of Egypt where the Islamic reformers (mujaddid) such as alThanthawi, Jamaluddin al-Afghani, Muhammad 'Abduh, Rasyid Rida, and others lived. AlSya rawi, who was known as a popular thinker at that time, was also one of the contemporary mufassirs who had produced several interpretive works. ${ }^{5}$

Muhammad Mutawalli al-Sya rawi was born on Sunday, April 16, 1911 in Daqadus, a small town located not far from the city of Mayyit Ghamr, al-Dahaliyyat Province, Egypt. He died on 17 June 1998 and was buried in the Daqadus area. ${ }^{6}$ His father gave the title "Amen" and this title is known to the public in the area. He is the father of three sons and two daughters named Sami, Abdurrahim, Ahmad, Fatima, and Salihah. ${ }^{7}$ The author assumes the title 'Amen' given to alSya 'rawi is related to his honesty and

\footnotetext{
Syarâwi," 71 .

${ }^{6}$ Muhammad Firdaus, "Al-'Izham Dalam AlQur'an Dan Relevansinya Dengan Proses Penciptaan Dan Kebangkitan Manusia (Studi Komparatif Antaratafsîr AlKabîr Aw Mafâtîh Al-Ghaib Dan Tafsir Khawatir AsSya'râwî Haul Al-Qur'an Al-Karim)" (Skripsi, Universitas Islam Negeri Sultan Syarif Kasim Riau, 2017), Https:/ /Doi.Org/10/Daftar\%20pustaka-Baru.Pdf.

${ }^{7}$ Ahmad Al-Masri Husain Jauhar, Al-Syaikh Muhammad Mutawalli Al-Sya'Râwi (Chairo: Nahdat Mishr,
}

${ }^{5}$ Rizqi, "Tafsir ilmi Dalam Kitab Tafsîr Al1990), 14 
trustworthiness. As well as the title al-Amin in Rasulullah SAW.

Also, he is one of the most famous mufassirs of the Qur'an in modern times, ${ }^{8}$ he can interpret religious matters very easily and simply, he also has enormous and noble efforts in the field of islamic teaching. He is known for his good and easy method of interpreting the Qur'an, and focusing on the points of faith in interpreting it, this is what makes him close to the human heart, especially his method is very suitable for all circles and cultures so that he is considered to have a Muslim personality who loves and respect Egypt and the Arab world more. Therefore he was also given the title "Imâm Ad-Du'âti".

In connection with the lineage (descent) of al-Sya rawi, in a book entitled Anâ min Sulâlat Abl al-Bait, al-Sya rawi mentions that he is a descendant of the grandchildren of the prophet, Hasan, and Husain. ${ }^{10}$ He grew up in a respectable family environment with ties to the scholars and saints. ${ }^{11}$ His father was a simple farmer who cultivated other people's land. However, alSya 'rawi's father had a love for knowledge and often went to assemblies to listen to the lecture of the scholars. ${ }^{12}$ He has a great desire and desire to direct his son to become a scientist. To realize this dream, he always monitored little al-Sya rawi while he was studying. He wants al-Sya rawi to enter al-Azhar University one day. Al-Sya rawi himself acknowledged the big role of the father in shaping his personality. It is as if al-Sya rawi took $10 \%$ from his teacher, then $90 \%$ was obtained from his father. ${ }^{13}$

${ }^{8}$ Muhammad `Ali Iyyazi, Al-Mufassirûn Hayâtubum Wa Manhajubum (Teheran: Mu'assasah Al-Thabâ`Ah Wa AlNasyr, 1372), 268.

${ }^{9}$ Muhammad Anshori, "Rahmatan Lil 'Alamin Dalam Tafsir Al-Mishbah Karya Quraish Shihab" (Yogyakarta, Uin Sunan Kalijaga, 2016).

${ }^{10} \mathrm{Sa}{ }^{\prime} \hat{I} d \mathrm{~d}$ Abû Al-`Ainain, Al-Sya Râwi Anâ Min Sulâlat Abl Al-Bait (Chairo: Akhbâr Al-Yaum, 1995), 6.

Sya`Râwi, 59

11Jauhar, Al-Syaikh Mubammad Mutawalli AlAl-Bait, 16.

${ }^{12}$ Abû Al-`Ainain, Al-Sya 'Râwi Anâ Min Sulâlat Abl

${ }^{13} \mathrm{Abu \hat { } \mathrm { Al }}$ `Ainain, 20.
The Daqadus area is filled with strong religious nuances. The busyness of religious holidays throughout the year colors this city. In this city, there are five Syekh leaders of the tarekat along with their respective followers to enliven the atmosphere of celebrating religious holidays that take place each month. while the province of al-Dahiliyyat itself is a productive province that gave birth to generations of geniuses who made many valuable contributions to the Egyptian state.

\section{Educational History}

At the age of 11 years, he had memorized the Qur'an. Al-Sya'rawi was registered at Madrasah Ibtidaiyah (basic education institution) alAzhar, Zaqaziq in 1926. Since he was a child, his intelligence has arisen in memorizing sya'ir (poetry) and Arabic proverbs from a word and wisdom, then getting al-Azhar Madrasab Ibtidaiyah diploma in $1923 .{ }^{14}$

Entering the Madrasab Tsanawiyah (secondary education institution), his interest in poetry and literature increased, and he had earned a special place among his peers, as well as being elected chairman of the student association and head of the literary association in Zaqaziq. And with him at that time Dr. Muhammad Abdul Mun'im Khafaji, poet Thahir Abu Fasya, Prof. Khalid Muhammad Khalid, Dr. Ahmad Haikal, and Dr. Hassan Gad. They showed him what they wrote. That was the point of change in alSya'rawi's life when his parents wanted to register him at al-Azhar, Cairo. He wanted to live with his brothers to farm, but his parents urged him to accompany him to Cairo, and pay for everything and prepare a place for his residence. Al-Sya'rawi gave conditions to his parents to buy many master books in classical literature, language, the science of the Qur'an, tafsir, hadith, as a kind of weakening him until his parents blessed him by returning to his home village.

${ }^{14}$ Ahmad 'Umar Hasyim, Al-Imâm Al- Sya'râmi Mufassiran Wa Dẩiyah (Chairo: Akhbâr Al-Yaum, 1998), 24. 
But his father was smart at the trick, and bought what was asked of him, saying: "I know my son that all these books are not obligatory for you, but I chose to buy them to provide interesting knowledge so that you will thirst for knowledge". He did not want to study with the Shaykh, except because he was obedient to his father, and this was a challenge for him to study seriously so that he could return home to his hometown with useful knowledge. ${ }^{15}$

Al-Sya'rawi was enrolled in the Faculty of Arabic in 1937 M, and he was busy with the national movement and the al-Azhar movement. In 1919 M a revolution broke out in al-Azhar, then al-Azhar issued an announcement reflecting the annoyance of the Egyptians against the British colonialists. The Zaqaziq Institute is not far from the sublime al-Azhar fortress in Cairo, al-Sya'rawi and his associates walked towards alAzhar's courtyard and beyond, and delivered orations of something that demonstrated his detention more than once, and at that time he is the Chairman of the Student Association. ${ }^{16}$

\section{Work History}

Al-Sya'rawi graduated in $1940 \mathrm{M}$ and obtained his bachelor's degree and was allowed to teach in 1943 M. After graduating al-Sya'rawi was assigned to a religious boarding school in Thanta. After that he was transferred to the religious boarding school in Zaqaziq, then the religious boarding school in Alexandria. ${ }^{17}$

After a long period of experience, alSya'rawi moved to work in Saudi Arabia in 1950, as a shari'ah lecturer at Umm al-Qurâ University. Al-Sya'rawi was forced to teach aqidah material even though his specialty was in the field of language, and basically, this caused great difficulties, but al-Shaywi was able to overcome it with the excellence that was in him with high

\footnotetext{
15Jauhar, Al-Syaikh Muhammad Mutawalli AlSya Râwi, 62-63.

${ }^{16} \mathrm{Abû}$ Al- 'Ainain, Al-Sya 'Râwi Anâ Min Sulâlat Abl Al-Bait, 28-29.

${ }^{17}$ Jauhar, Al-Syaikh Mubammad Mutawalli AlSya Râmi, 212-13.
}

achievements, and because of that influence President Jamal Abdul Naser forbade al-Sya'rawi to return to Saudi Arabia. ${ }^{18}$

In 1963, there was a dispute between president Jamal Abdul Naser and the King of Saudi. After that al-Sya'rawi received an award and was assigned to Cairo as Director at the office of Sheikh al-Azhar Sheikh Husein Ma'mun. Then he went to Algeria as the chief ambassador of al-Azhar there and stayed for seven years, and returned to Cairo to be assigned as Head of the Department of Religion of Gharbiyah province, then he became Deputy of Da'wah and Thought, and became the envy of al-Azhar for the second time to the Kingdom of Saudi Arabia, teaching at King Abdul Aziz University. ${ }^{19}$

In November 1976, Prime Minister Sayyid Mamduh Salim elected a member of his ministry, al-Sya'rawi assigned to the Department (affairs) of Waqf and al-Azhar Affairs (the level of the Minister of Religion in Indonesia) until October 1978. ${ }^{20}$ After leaving a good influence for economic life in Egypt, he was the first to issue a ministerial decree regarding the establishment of the first Islamic bank in Egypt, namely the Faisal Bank, and this is the authority of the Minister of Economy and Finance Dr. Hamid Sayih at this time was handed over to him.

\section{His Works}

Al-Sya'rawi has a number of written works, some people love to collect and compile them for distribution, while the most popular and most phenomenal work is Tafsir Al-Sya'rawi. Apart from that, his works include:

$$
\begin{aligned}
& \text { a. Al-Mukbtâr min Tafsîr al-Qur'ân al-Karîm, } 3 \\
& \text { volumes } \\
& \text { b. Mu'jizat al-Qur'ân al-Karim } \\
& \text { c. Al-Qur'ân al-Karim Mu'jizab wa Manhaj } \\
& \text { d. Al-Isrâ' wa al-Mi râj }
\end{aligned}
$$




\author{
e. Al-Qashsash al-Qur'âniy fî Sûrat al-Kahf \\ f. Al-mar'ah fì al-Qur'ân al-Karìm \\ g. Al-Ghaib \\ b. Mư jizât al-Rasûl \\ i. Al-Halal wa al-Haram \\ j. Al-Haij al-Mabrûr \\ k. Khawâthir al-Sya râwi haula 'Imrân al-Mujtama' \\ l. Al-Sibr wa al-Hasad \\ m. And Others.
}

\section{HISTORY OF WRITING TAFSIR $A L$ - $S Y A ' R A W I$}

This book is the result of creations made by students of al-Sya 'rawi, namely Muhammad alSinrawi and 'Abd al-Waris al-Dasuqi from a collection of speeches or lectures by al-Sya'rawi. Meanwhile, the traditions contained in the book Tafsir al-Sya'rawi were endorsed by Ahmad 'Umar Hâsyim. This book was published by Akhbâr alYaum Idârah al-Kutub was al-Maktabât in 1991 (seven years before al-Sya'rawi died). Before being published, this tafsir had been published in the magazine al-Liwa â 'from 1986 - 1989, in edition 251-332. ${ }^{21}$ Thus, this Tafsir al-Sya'rawi is a collection of the results of the speeches or lectures of al-Sya'rawi which are then edited in the form of written books by his students.

In the beginning, the Tafsir al-Sya'rawi, was not a work of tafsir that was deliberately compiled as a work of al-Qurân interpretation, but a documentary written from the recorded lecture of a great scholar of Egypt named Sheikh Muhammad Mutawalli al-Sya'rawi. Before becoming a work of interpretation, documentation of al-Sya'rawi's lectures was first published in the magazine al-Liwâ 'al-Islami. Then collected in the form of a book series called Khawâthiri haul al-Qurân al-Karîm, which was published starting in 1982 by the publisher Dâr Mayu al-Wathaniyyah. ${ }^{22}$

268.

${ }^{21}$ Iyyazi, Al-Mufassirûn Hayâtubum Wa Manhajubum,

${ }^{22}$ This Book Was Given An Introduction By Muhammad Abu Thâlîb Syâhîn. In his introduction he states that the book Khawathiri Hawl al-Qurân al-Karim is not
Al-Sya rawi in its muqaddimah tafsir states that 'The results of my reflections on al-Qur'an do not mean an interpretation of the al-Qur'an, but only the spark of thoughts that cross the heart of a believer when reading al-Qur' an'. If it is true that the Qur'an can be interpreted, in fact, the one who has the right to interpret it is only the Messenger of Allah, because it was to him that the Qur'an was revealed. He explained a lot to people about the teachings of the Qur'an from the dimension of worship, because that is what his people need today. As for the secret of the Qur'an about the universe, he did not convey it, because the socio-cultural conditions at that time did not allow him to accept it. If this is conveyed, it will cause a polemic which at one time will destroy the foundations of religion, and will even turn people away from the path of Allah SWT. ${ }^{23}$

Part of the foregoing is also found on the initial page of the book before muqaddimah (madkhal), ${ }^{24}$ in the form of al-Sya 'rawi's handwriting attached to the publisher. This (handwritten) appendix is also attached to the translated edition of the al-Sya rawi tafsir book.

The name Tafsir al-Sya'rawi is taken from the original name of its owner, namely Sheikh Muhammad Mutawalli al-Sya'rawi. According to Muhammad 'Ali Iyâzi the famous title of this work is Tafsîr al-Sya'rawi, Khawâtir al-Sya'rawi Haula al-Qur'ân al-Karim. At first, this interpretation was only given the name Khawatir al-Sya'rawi which was meant as a reflection (Khawatir) from alSya'rawi against the verses of the al-Qur'an.

In this tafsir, Sheikh Muhammad Mutawalli Sya'rawi first gave a fairly lengthy introduction (approximately 35 pages), which deals with the Qur'an and tafsir. In every

written in a speech style and scientific writing style, but is written in a lecture style to show that this book is intended for all groups and not certain groups so that its benefits are greater. See: Al-Sya'râwi, Khawathiri Hawl Al-Qurân AlKarìm, Vol. I (Kairo: Dâr Mayu Al-Wathaniyyah, 1982), 18.

${ }^{23}$ Muhammad Mutawalli Al-Sya Rawi, Tafsir AlSya Rawi (Chairo: Akhbâr Al-Yaum Idârah Al-Kutub Wa Al-Maktabât, 1991), 270.

${ }^{24}$ Muqaddimah In Book Of Tafsir Al-Sya Rawi Written By Madkhal 
introduction sheet, he always includes a verse and a history as reinforcement and conditioning the reader's heart. He said that the Qur'an must be made manhaj in human life and is a taklif law that must be followed, according to the introduction of his book..$^{25}$

Tafsir al-Sya'rawi, was called by that name because of the wishes of the publisher, began to be published in the form of tafsir in 1991, by the publisher Akbâr al-Yaum.

Tafsir Sya'râm î is not like other tafsir works because the purpose and objective are to express the 'Ijaz al-Qurân and convey the ideas of faith to viewers, listeners, and readers. Therefore, this book is not written in a speech-language style nor is it written in a scientific writing style but is written in a lecture-style from a teacher in front of students and listeners with varying levels of education and status. So the interpretation given by al-Sya 'râwî is inseparable from the miracles of the Qur'an and the teachings. Herein lies the difference between the Qur'an and the previous scriptures. That the Qur'an is not just a teaching but also a miracle that Allah sent down to the Prophet Muhammad.

This book is printed in 29 volumes. ${ }^{26}$ But from other references same say this book was written in 18 volumes with descriptions like the following:

- Volume I; Introduction, QS. al-Fatihah to QS. al-Baqarah verse 154

- Volume II; QS. al-Baqarah verses 155 to QS. Ali Imran verse 13.

- Volume III; QS. Ali Imran verses 14 to 189.

- Volume IV; QS. Ali Imran verses 190 to QS. An-Nisa 'verse 100.

- Volume V; QS. An-Nisa 'verses 101 to QS. Al-Maidah: 54.

- Volume VI; QS. Al-Maidah: 55 to QS. alAn'aam: 109.

- Volume VII; QS. al-An'aam: 110 to QS. alA'raf: 188.

${ }^{25}$ Al-Sya `Rawi, Tafsir Al-Sya Rawi, 41-43.

${ }^{26}$ Al-Sya Rawi, 41-43.
- Volume VIII; QS. al-A'raf: 189 to QS. AtTaubah: 44

- Volume IX; QS. At-Taubah: 45 to QS. Jonah: 14 .

- Volume X; QS. Yunus: 15 to QS. Hud: 27.

- Volume XI; QS. Hud: 28 to QS. Yusuf: 96.

- Volume XII; QS. Yusuf: 97 to QS. Al-Hjr: 47.

- Volume XIII; QS. Al-Hjr: 48 to QS. Al-Isra ': 4.

- Volume XIV; QS. Al-Isra ': 5 to QS. AlKahfi; 98.

- Volume XV; QS. Al-Kahfi; 99 to QS. AlAnbiya ': 90.

- Volume XVI; QS. Al-Anbiya ': 91 to QS.anNur: 35.

- Volume XVII; QS.an-Nur: 36 to QS. AlQasas: 29.

- Volume XVIII; QS. Al-Qasas: 30 to QS. ArRum: 58.

The author assumes that the above information may not include all the volumes that have been printed, or because of incomplete references, because the book of al-Sya rawi tafsir that is in the author's hands currently amounts to 20 volumes, where volume 20 starts from the verse al-Ahzab 64 to Surah al-Shaffat verse 138. The complete description of the book is as follows:

- Volume XIX; QS. Al-Rum: 59 to QS. alAhzab: 63

- Volume XX; QS. Al-Ahzab: 64 to QS. alShaffat verse 138

However, according to the author, this may be due to a lack of the writer's collection, because Muhammad 'Ali Iyâzi stated that this book was printed in 29 volumes, covering all 30 juz verses of the Qur'an. This writer also understands from Abu Irfah's statement which states that the Tafsir al-Sya'rawi has been translated into Indonesian by the Indonesian Safir Al-Azhar Translation Team, chaired by Zainal Arifin. Abu Irfah said, 'I know that this tafsir has 
been translated from chapters 1 to 30, except chapters 27 to chapters 29. This interpretation consists of 13 volumes. In my collection, there are only volumes $1-5$. Also, he also said that the content of al-Sya'rawi's lecture which interpreted Juz 'Amma had also been recorded and published by the Egyptian publisher Dâr al-Râyah in 2008. ${ }^{27}$

One thing that is unique in the tafsir of alSya rawi which the author is researching lies in numbering. The first page in volume 2 was written continuation from the last page in volume 1. So, until the end of the volume, the page numbering was written to continue. In the last volume of the author's collection (volume 20), the last page is page 12832 .

The source of interpretation in the tafsir al-Sya'rawi in conducting exegetical activities, alSya'rawi uses interpretation sources that are by the rules of bil ma'tsur and bi al-ra'y, where the main sources of interpretation it uses consist of three types: interpretation of the Qur'an with the Qur'an, al-quran with history, and interpretation of the Qur'an with qoul al-shabâbah.

\section{METHOD AND STYLE OF INTERPRE- TATION OF AL-SYA'RAWI}

In general, the mufassir uses a method that is inseparable from the four methods of interpretation, namely tabliliyy, ijmâlî, muqâran, and maudhu'î. The general method used by al-Sya'rawi in its interpretation is the tahlilityy method, which explains the meaning of the verses of al-qurân from various aspects, by paying attention to the order of the verses as stated in the mushbaf. ${ }^{28}$

The steps taken by al-Sya'rawi are by the characteristics of the tafsir that uses the tablitiyy method, explaining vocabulary and lafazh, namely explaining the desired meaning, the intended target, and the contents of the verse, the elements of i'jâr, balâghah, and the beauty of sentence structure, explaining the istinbath of the verse, and

\footnotetext{
${ }^{27}$ Rizqi, "Tafsirilmi Dalam Kitab Tafsîr AlSyarâwi."

${ }^{28}$ Al-Farmawi, Al-Bidâyah Fî̀ Al-Tafsîr Al-Maudu'î, (Chairo, 1977), 24.
}

suggesting the relationship between the verses and their relevance to the surah before and after (munâsabât al-âyât wa al-suwar), by referring to asbâb al-nuгûl, the traditions of the Prophet Muhammad and also the history of tabi'in. ${ }^{29}$

Imam Sya'rawi in his interpretation tends to use the al-Adabiy al-Ijtimâ'iy style. This can be seen from several examples:

1. Provide actual and contemporary examples to bring the meaning that was originally considered for closer and understood by both the listener and the reader, so that it sinks into the heart. The interpretation of alSya'rawi by revealing examples of expressions or examples of contemporary reality is marked by the expressionalSya'rawi: "مثنا" or "أضرب or المثنال or "وضربنا مثنا لذلك" For example, at the time of al-Sya ' râwî interprets QS al-Baqarah (2): 174

2. Explaining the verse with an understanding based on reality, with the aim that the values contained in al-qurân can be implemented or actualized in human life on earth. This is at the same time to show that the purpose of being revealed by al-qurân is budan li al-nâs and rahmatan li al-'álamîn.

3. Using the dialogue model; questions and answers, to explain things that exist and the meaning of the verse. The model of interpretation which is packaged in the question-jwab expression in the Tafsir alSya'rawi can be stated as very dominant. This happens because the beginning of this interpretation is spoken language, not written language so that the expression in dialectical language is easier and can be understood quickly by the listener. As an example can be seen the interpretation of Q.S. Fathir (35): 29-30

4. Using the symbolic theory of certain words or sentences contained in the verse. The use of symbolic theory is also used by al-Sya'rawi

${ }^{29}$ Ali Hasan Al-'Aridh, Tarîkh Ilm Al-Tafsîr Wa Manâhij Al-Mufassirîn (Dâr Al-I'tishâm, N.D.), 47. 
to explain his interpretation. The symbolic meaning taken by al-Sya'rawi can be from words or sentences, such as in interpreting the Q.S. al-Baqarah (2): 35

\section{ANALYSIS OF STRENGTHS AND WEAKNESSES OF TAFSIR AL-SYA'RAWI}

This book is a fairly calculated modern interpretation. As one proof of this, after this book was completed and printed, al-Sya rawi received a great welcome from Egyptian scholars at that time. Also, he also received gifts from Kuwait up to thousands of dollars, ${ }^{30}$ which were donated to help Thai students at that time.

There are many strenghts possessed by alSya 'rawi's interpretation, including al-Sya rawi presents his interpretive works with nuances that are in direct contact with social themes, through fairly simple language techniques. This is an effort to put the Qur'an in a position as a guide in the reality of social life. As well as in the interpretation of al-Sya rawi, the content in it can answer the problems of society which is always developing because it uses the al-Adabiy al-Ijtima ${ }^{\prime} i$ style.

The author sees the shortcomings in this interpretation lies in the absence of a reference when there is mention of an opinion of another ulama. And there is no assessment of the quality of the hadiths quoted in the tafsir, but the author of the book only mentions the narrators of the hadith at the mukharrij level.

In interpreting the Qur'an, al-Sya'rawi does not include quotations from the opinions of the mufassirs, both classical and modern. The author assumes, in quoting an opinion, alSya rawi directly analyzes that opinion. Opinions that are by his understanding are put into his

${ }^{30}$ This information was obtained from several students who had studied at al-Azhar University. They also argue that there are two opinions regarding the completion of the book: first, the writing of the commentary book has been completed in the form of a binding before death picks him up; second, there are also those who say that the interpretation has been completed by 30 juz, but only part of it has been bound, then he die.
Tafsir, while opinions that are not by his line of thought are only used as comparison material in his interpretation of the verses of the Qur'an.

Regardless of whether he quoted or not in interpreting the verses of the Qur'an, what is clear in his book is that there are no quotes like other commentaries, as is the case with the Tafsir Ma'âni al-Tan₹̨il by Sheikh al-Baghâwi. This shows that al-Sya'rawi has consistency regarding the authenticity of the Qur'an as a miracle, which can answer all the problems of interpretation that are raised by the Qur'an itself.

On the other hand, he did not use language that was difficult to digest in his tafsir but on the contrary which was easy to understand, because of his position as a preacher. Logically, a preacher will be liked and favored by the audience because the language spoken is easy and can be clearly understood by all audiences. This seems to be seen in his interpretation. All of these methodologies seem inseparable from Sheikh Muhammad Mutawalli Sya'rawi's background as a preacher.

\section{CONCLUSION}

Based on the results of the research conducted, it can be concluded that the book Tafsir al-Sya rawi is the work of a prominent scholar from Egypt named Sheikh Muhammad Mutawally al-Sya râwi, born in 1911 in Egypt. The name Tafsir al-Sya'rawi was taken from the original name of its owner, namely Sheikh Muhammad Mutawalli Sya'rawi. This interpretation uses the tahlili method and is characterized by al-adab al-ijtima'i.

One of the advantages possessed by this interpretation is the presentation of the interpretation with nuances that is in direct contact with social themes, through a fairly simple language technique. This is an effort to put the Qur'an in a position as a guide in the reality of social life. As well as in the interpretation of al-Sya rawi, the content in it can answer the problems of society which is always 
developing because it uses the al-Adabiy al-Ijtima ${ }^{\prime} i$ style.

Among the shortcomings it has is the absence of a reference source when there is a mention of quoting the opinion of other scholars. And there is no assessment of the quality of the hadiths that he quoted, but the author of the book only mentions the narrators of the hadith at the mukharrij level.

\section{REFERENCES}

Abû Al-`Ainain, Sa`id. Al-Sya'Râwi Anâ Min Sulâlat Abl Al-Bait. Cairo: Akhbâr AlYaum, 1995.

Al-Farmawi. Al-Bidâyah Fî̀ Al-Tafsîr Al-Maudu'î,. Cairo, 1977.

Anshori, Muhammad. "Rahmatan Lil 'Alamin Dalam Tafsir Al-Mishbah Karya Quraish Shihab.” Uin Sunan Kalijaga, 2016.

'Aridh, Ali Hasan Al-. Tarikh Tlm Al-Tafsîr Wa Manâhij Al-Mufassirinn. Dâr Al-I'tishâm, N.D.

Hakim, Lukmanul, Asrizal Asrizal, Afrizal Nur, And Agustiar Agustiar. "Qur'anic Interpretation Method And Its Impact On Contemporary Interpretation." Jurnal Ushuluddin 26, No. 2 (December 13, 2018): 142-53. Https://Doi.Org/10.24014/Jush.V26i2.4 577.

Hasyim, Ahmad 'Umar. Al-Imâm Al- Sya'rawi Mufassiran Wa Dâizyah. Cairo: Akhbâr AlYaum, 1998.

Iyyazi, Muhammad `Ali. Al-Mufassirûn Hayâtubum Wa Manhajubum. Teheran: Mu'assasah AlThabâ`Ah Wa Al-Nasyr, 1372.

Jauhar, Ahmad Al-Masri Husain. Al-Syaikh Muhammad Mutawalli Al-Sya Râwi. Cairo: Nahdat Mishr, 1990.

Minsyâwî, Muhammad Siddîq Al-. Al-Syaikh AlSya'rawi Wa Hadits Al-Drikrayât, N.D.

Muhammad Firdaus. "Al-'Tzham Dalam AlQur'an Dan Relevansinya Dengan Proses Penciptaan Dan Kebangkitan Manusia (Studi Komparatif Antaratafsîr Al-Kabîr
Aw Mafâtîh Al-Ghaib Dan Tafsir Khawatir As-Sya'râwî Haul Al-Qur'an AlKarim)." Skripsi, Universitas Islam Negeri Sultan Syarif Kasim Riau, 2017. Https://Doi.Org/10/Daftar\%20pustakaBaru.Pdf.

Rizqi, Muhammad. "Tafsir ilmi Dalam Kitab Tafsîr Al-Syarâwi." Al-Furqan 3, No. 2 (2016): 70-81.

Sardar, Ziauddin. Reading The Qur'an: The Contemporary Relevance Of The Sacred Text Of Islam. Oxford University Press, 2011.

Sya rawi, Muhammad Mutawalli Al-. Tafsir AlSya Rawi. Cairo: Akhbâr Al-Yaum Idârah Al-Kutub Wa Al-Maktabât, 1991. Khawathiri Hawl Al-Qurân Al-Karim. Vol. I. Kairo: Dâr Mayu Al-Wathaniyyah, 1982.

Y1lmaz, Hakk1. The Division By Division English Interpretation Of The Qur'an In The Order Of Revelation. Hakk1 Yilmaz, 2020. 